\title{
Association of a PARK2 Germline Variant and Epithelial Ovarian Cancer in a Southern Brazilian Population
}

\author{
Phamela Ferreira Klimczak ${ }^{a}$ Danielle Hornung Ventury ${ }^{a}$ Fabio Rueda Faucz ${ }^{b}$ \\ Nikolaos Settas $^{\mathrm{b}}$ Cleber Machado de Souza $^{\mathrm{a}}$ Vanessa Santos Sotomaior $^{\mathrm{a}}$ \\ ${ }^{a}$ Graduate Program in Health Sciences, School of Medicine, Pontifícia Universidade Católica do Paraná (PUCPR), \\ Curitiba, Brazil; bSection on Endocrinology and Genetics, Program on Developmental Endocrinology and Genetics, \\ Eunice Kennedy Shriver National Institute of Child Health and Human Development, National Institutes of Health, \\ Bethesda, Md., USA
}

\section{Key Words}

Epithelial ovarian cancer · Ovarian cancer · Ovarian

carcinoma - Cancer genetic susceptibility · Tag SNP . PARK2 .

Tumor suppressor gene

\begin{abstract}
Ovarian cancer (OC) is the eighth most common cancer among women in Brazil and seventh in the world population. OC has a high mortality rate and is difficult to diagnose. Currently, OC detection most often occurs at an advanced stage of the disease due to its silent progression, which contributes to the high mortality rate. Available genetic markers are not considered specifically enough for an initial and definite diagnosis. The association with new genes involved with OC can provide a better understanding of this pathology as well as contribute to the development of a marker scenario, providing an improvement in the treatment and survival of patients. The aim of this study was to examine the potential association between the PARK2 gene and epithelial ovarian cancer (EOC). Accordingly, we conducted a study for which 25 patients and 87 controls were recruited. Link-
\end{abstract}

age disequilibrium analysis showed that the four studied tag SNPs (rs2803073, rs6930532, rs1040079, and rs2276201) were independent. Our results using the multivariate analysis between the additive and dominant model demonstrated that tag SNP rs 2803073 of PARK2 is associated with susceptibility to EOC $(p=0.018, O R=0.42)$. These findings suggest that hereditary variation in the PARK2 gene could influence EOC development mechanisms.

(c) 2016 S. Karger AG, Basel

\section{Introduction}

Ovarian cancer (OC) is the eighth most common cancer among women in Brazil [1] and seventh in the world population [2]. OC has a high mortality rate and is difficult to diagnose [3]. It is highly heterogeneous according to cell origin and can be classified into three types: epithelial, stromal, and germ cell. The epithelial form occurs in $90 \%$ of all cases [4]. Currently, OC detection most often occurs at an advanced stage of the disease due to its silent progression, which contributes to the high mortality rate [3].

\section{KARGER}

E-Mail karger@karger.com www.karger.com/ocl (c) 2016 S. Karger AG, Base

0030-2414/16/0912-0101\$39.50/0
Dr. Vanessa Santos Sotomaior

Programa de Pós-Graduação em Ciências da Saúde Escola de Medicina, Pontifícia Universidade Católica do Paraná Rua Imaculada Conceição, 1155, Curitiba, PR 80215-901 (Brazil) E-Mail vanessa.sotomaior@ pucpr.br 
Table 1. Genotypic analysis of tag SNPs of the PARK2 gene in an additive model

\begin{tabular}{|c|c|c|c|c|c|c|}
\hline Tag SNPs ${ }^{\mathrm{a}}$ & Variation [1/2] & Groups & Homozygote 1 & Heterozygote & Homozygote 2 & $\mathrm{p}$ value* \\
\hline \multirow{3}{*}{ rs1040079 } & \multirow{3}{*}[\mathrm{C}/\mathrm{T}]{} & & $\mathrm{TT}$ & $\mathrm{CT}$ & $\mathrm{CC}$ & \multirow{3}{*}{0.897} \\
\hline & & Control & $34(39.1)$ & $39(44.8)$ & $10(11.5)$ & \\
\hline & & Cases & $12(48.0)$ & $10(40.0)$ & $2(8.0)$ & \\
\hline \multirow{3}{*}{ rs2276201 } & \multirow{3}{*}[\mathrm{A}/\mathrm{G}]{} & & $\mathrm{AA}$ & GA & GG & \multirow{3}{*}{0.732} \\
\hline & & Control & $30(34.5)$ & $40(46.0)$ & $12(13 . e 8)$ & \\
\hline & & Cases & $11(44.0)$ & $11(44.0)$ & $2(8.0)$ & \\
\hline \multirow{3}{*}{ rs6930532 } & \multirow{3}{*}[\mathrm{C}/\mathrm{T}]{} & & $\mathrm{TT}$ & $\mathrm{CT}$ & $\mathrm{CC}$ & \multirow{3}{*}{0.409} \\
\hline & & Control & $54(62.1)$ & $28(32.2)$ & $2(2.3)$ & \\
\hline & & Cases & $19(76.0)$ & $5(20.0)$ & $1(4.0)$ & \\
\hline \multirow{3}{*}{ rs 2803073} & \multirow{3}{*}[\mathrm{C}/\mathrm{T}]{} & & $\mathrm{TT}$ & $\mathrm{CT}$ & $\mathrm{CC}$ & \multirow{3}{*}{0.621} \\
\hline & & Control & $39(44.8)$ & $27(31.0)$ & $11(12.6)$ & \\
\hline & & Cases & $8(32.0)$ & $14(56.0)$ & $1(4.0)$ & \\
\hline
\end{tabular}

Studies show an increased risk of development in women with mutations in the BRCA1 (breast cancer 1), BRCA2 (breast cancer 2), PTEN (phosphatase and homolog tensin), and TP53 (protein tumor p53) genes, which are currently used as markers [5]. However, they are not considered specific enough for an initial and definite diagnosis [6].

PARK2 (parkin RBR E3 ubiquitin protein ligase) [7] encodes the parkin protein that is involved in many cellular processes such as proteasome degradation, xenophagy, cycle control, proliferation and cellular migration, response to oxidative stress, mitochondrial homeostasis, and tumor suppression [8-12]. Mutations in PARK2 have been associated with juvenile autosomal recessive Parkinsonism [13], leprosy [14], diabetes mellitus type 2 [15], Alzheimer's dementia [16], multiple sclerosis [17], attention deficit hyperactivity disorder [18], autism [19], typhoid and paratyphoid fever [20, 21], and more recently to cancer [22]. Among the cancers already presenting PARK2 alterations are: ovarian, breast, kidney, lung, liver, colorectal, melanoma, acute lymphoblastic leukemia, Burkitt's lymphoma, and B-cell nonHodgkin's lymphoma [23].

The association of new genes involved with OC can provide a better understanding of this pathology, as well as contribute to the development of a marker scenario, providing an improvement in the treatment and survival of patients [24]. The aim of this study was to examine the potential gene association between PARK2 and OC.

\section{Materials and Methods}

We obtained peripheral blood samples from 25 white female patients from Erasto Gaertner Hospital, Curitiba, Brazil, diagnosed with epithelial ovarian cancer (EOC) and confirmed by pathological examination. Those under radiotherapy and chemotherapy treatment were excluded. In addition, we included 87 peripheral blood samples of white female controls unrelated to each other from the Hemobanco, Curitiba, Brazil, forming a Southern Brazilian population.

After sample collection, a DNA extraction and purification was carried out by the salting-out technique $[25,26]$. Subsequently the samples were diluted, quantified, and stored at $-4^{\circ} \mathrm{C}$ until the time of use.

The genotyping of PARK2 was performed using the Applied Biosystems 7500 Real-Time PCR System and the TaqMan ${ }^{\mathrm{TM}}$ technology. The amounts and conditions were defined by the manufacturer's specifications. The markers of tag SNP type (rs2803073, rs6930532, rs1040079, and rs2276201) were selected according to the information from the International HapMap Project and in order to allow for a wide coverage of the gene.

The results were analyzed by SPSS 13.0 software, and the differences were considered significant when the $\mathrm{p}$ value was $<0.05$. Based on logistic regression, the ORs of the analyzed alleles were calculated. The degree of linkage disequilibrium (LD) expressed by the parameter $r^{2}$ between the four markers was analyzed using the Haploview 4.2 program. The same program was used to verify if the distribution of allele and genotype frequencies were in HardyWeinberg equilibrium.

The tool Firebrowse (http://firebrowse.org/) of the Broad Institute was used for the analysis of The Cancer Genome Atlas (TCGA) ovarian serous cystadenocarcinoma data regarding the PARK2 gene. Moreover, an additional analysis was performed using the available data from the catalogue of somatic mutations in cancer (COSMIC; http://cancer.sanger.ac.uk/cosmic) regarding ovarian carcinoma and PARK2 gene aberrations. 
Statement of Ethics

All participants signed an informed consent form, authorizing their participation in the study. The project was approved by the PUCPR Research Ethics Committee under the Protocol No. $3983 / 10$.

\section{Results}

Allele frequencies observed between the patients and controls are shown in table 1. This univariate analysis showed no significant difference between EOC and the markers rs1040079 ( $\mathrm{p}=0.897), \operatorname{rs} 2276201(\mathrm{p}=0.732)$, rs6930532 ( $\mathrm{p}=0.409)$, and $\mathrm{rs} 2803073$ ( $\mathrm{p}=0.621)$. To investigate whether or not the combination of these tag SNPs could influence the development of EOC, and given that it was not possible to explain the susceptibility only by additive and dominant models independently, a multivariate analysis involving the additive and dominant models was performed. This analysis showed a significant association ( $\mathrm{p}=0.018$ ) between EOC and the marker rs2803073 (table 2).

LD analysis showed that the markers are independent (fig. 1), with a low LD between rs1040079 and rs2276201 tag SNPs. All polymorphisms were in Hardy-Weinberg equilibrium.

Taking into consideration the data related to ovarian serous cystadenocarcinoma from the TCGA database, the above-mentioned SNPs have not been described in this type of cancer yet. The same applies to the COSMIC data. This database included only one coding mutation (p.R191R) of the PARK2 gene in 1 out of the 115 studied patients with ovary carcinoma.

\section{Discussion}

$\mathrm{OC}$ has been associated with somatic changes in several genes, including OPCML [27], PIK3CA [28], AKT1 [29], CTNNB1 [30], and PARK2 [7]. Germline mutations in the $M L H 1$ gene were associated with susceptibility to familial OC [31]. In the present study, we analyzed changes in germline PARK2; therefore, an association with the development of EOC could occur in the hereditary form.

One of the mechanisms of action described for parkin is cell cycle regulation through degradation control of cyclins $\mathrm{D}$ and $\mathrm{E}$, which could be related to its role as a tumor suppressor [32]. This protein can also regulate oxidative stress, as well as the Warburg effect, both reported in tumor cells [33]. Alterations in TP53, commonly described in tumors, may contribute to the downregulation of the
Table 2. Multivariate analysis for an additive-dominant model of the four tag SNPs of the PARK2 gene

\begin{tabular}{|c|c|c|c|c|}
\hline Variable & p value* & OR & $\begin{array}{l}\text { Inf. lim. } \\
95 \%\end{array}$ & $\begin{array}{l}\text { Sup. lim. } \\
95 \%\end{array}$ \\
\hline rs1040079 ADD & 0.534 & 2.560 & 0.133 & 49.329 \\
\hline rs1040079 DOM & 0.612 & 2.811 & 0.052 & 152.040 \\
\hline rs2276201 ADD & 0.276 & 0.162 & 0.006 & 4.290 \\
\hline rs2276201 DOM & 0.402 & 0.175 & 0.003 & 10.306 \\
\hline rs6930532 ADD & 0.125 & 14.949 & 0.470 & 475.373 \\
\hline rs6930532 DOM & 0.081 & 33.420 & 0.649 & $1,721.072$ \\
\hline rs2803073 ADD & 0.072 & 0.132 & 0.015 & 1.195 \\
\hline rs2803073 DOM & 0.018 & 0.042 & 0.003 & 0.576 \\
\hline
\end{tabular}

* Logistic regression model and Wald test, $\mathrm{p}<0.05 . \mathrm{ADD}=$ Additive; DOM = dominant.

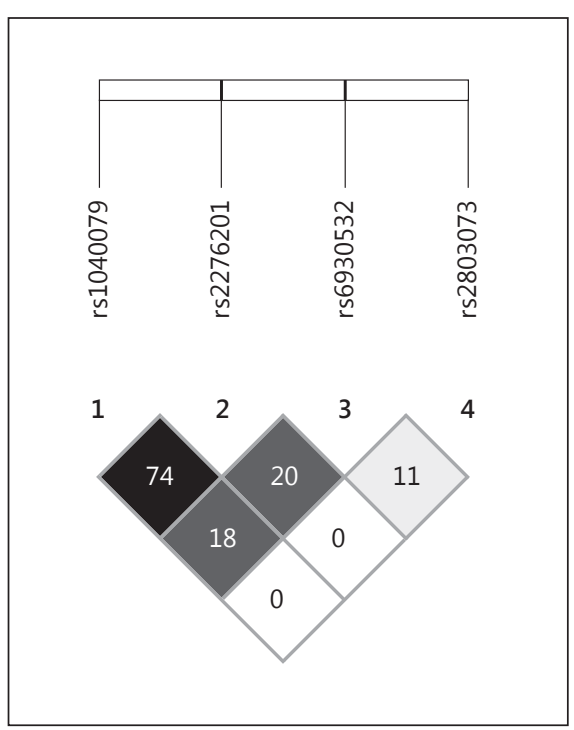

Fig. 1. Representation of the LD structure between the tag SNPs of the gene PARK2. The values for LD are presented within each square.

expression of $P A R K 2$, resulting in its low transcription [33].

The LD analysis showed that tag SNPs are independent [34]. Our results using the multivariate analysis between the additive and dominant model demonstrated that tag SNP rs2803073 of PARK2 is associated with susceptibility to EOC $(\mathrm{p}=0.018, \mathrm{OR}=0.42)$. This suggests that a combination of alleles of this gene by unclear mechanisms could result in a genotype of risk for the development of EOC. These findings suggest that hereditary vari- 
ation in the PARK2 gene could influence cancer development mechanisms.

The data from OC patients included in the TCGA and COSMIC databases unfortunately did not include any intronic alterations of the PARK2 gene. As a result, no further correlation with other studied samples could be performed.

Despite the limited PARK2 data in OC patients, one could speculate that in the intronic regions where these SNPs are located, a potential miRNA could be allocated that could upregulate the expression of the PARK2 gene in this type of cancer. This hypothesis can be supported from other studies that suggest that miRNA intronic expression is upregulated in cancer cells $[35,36]$.
Considering the correlation with several types of cancer [22], including OC [37], our results suggest that PARK2 could also be used as a genetic biomarker for tumor diagnosis, leading to a better understanding of the pathogenesis of EOC.

\section{Acknowledgements}

We thank Dr. Reitan Ribeiro, Dr. José Linhares, and Dr. José Antonio Guerrero for their help in the recruitment of patients and the collection of blood samples in Erasto Gaertner Hospital, as well as Prof. Dr. Marcelo Távora Mira for the help with the probes used in this project. We thank Diane Cooper, MSLS, NIH Library, for providing assistance in writing the manuscript.

\section{References}

1 Estimativa 2016: incidência de câncer no Brasil / Instituto Nacional de Câncer José Alencar Gomes da Silva - Rio de Janeiro: INCA, 2015

2 World Cancer Research Fund, American Institute for Cancer Research: Worldwide data: a global perspective. Washington, AICR, 2015.

-3 Cannistra SA: Cancer of the ovary. N Engl J Med 2004;351:2519-2529.

4 Ristow CM, Yamamoto CT, Fávaro M: Risk factors and pathogenesis of malignant epithelial ovarian neoplasm: a literature review. Rev Bras Cancerol 2006;52:185-195.

5 Bast RC, Hennessy B, Mills GB: The biology of ovarian cancer: new opportunities for translation. Nat Rev Cancer 2009;9:415-428.

6 Kwon MJ, Shin YK: Epigenetic regulation of cancer-associated genes in ovarian cancer. Int J Mol Sci 2011;12:983-1008.

-7 Cesari R, Martin ES, Calin GA, Pentimalli F, Bichi R, McAdams H, Trapasso F, Drusco A, Shimizu M, Masciullo V, D’Andrilli G, Scambia G, Picchio MC, Alder H, Godwin AK, Croce CM: Parkin, a gene implicated in autosomal recessive juvenile parkinsonism, is a candidate tumor suppressor gene on chromosome 6q25-q27. Proc Natl Acad Sci USA 2003; 100:5956-5961.

8 Bouman L1, Schlierf A, Lutz AK, Shan J, Deinlein A, Kast J, Galehdar Z, Palmisano V, Patenge N, Berg D, Gasser T, Augustin R, Trümbach D, Irrcher I, Park DS, Wurst W, Kilberg MS, Tatzelt J, Winklhofer KF: Parkin is transcriptionally regulated by ATF4: evidence for an interconnection between mitochondrial stress and ER stress. Cell Death Differ 2011;18:769-782.

9 Klinkenberg M, Gispert S, Dominguez-Bautista JA, Braun I, Auburger G, Jendrach M: Restriction of trophic factors and nutrients induces PARKIN expression. Neurogenetics 2012;13:9-21.
10 Wang HQ, Imai Y, Kataoka A, Takahashi R: Cell typespecific upregulation of parkin in response to ER stress. Antioxid Redox Signal 2007;9:533-542.

11 Kim KY, Stevens MV, Akter MH, Rusk SE, Huang RJ, Cohen A, Noguchi A, Springer D, Bocharov AV, Eggerman TL, Suen DF, Youle RJ, Amar M, Remaley AT, Sack MN: Parkin is a lipid-responsive regulator of fat uptake in mice and mutant human cells. J Clin Invest 2011;121:3701-3712.

12 Ikeuchi K, Marusawa H, Fujiwara M, Matsumoto Y, Endo Y, Watanabe T, Iwai A, Sakai Y, Takahashi R, Chiba T: Attenuation of proteolysis-mediated cyclin E regulation by alternatively spliced parkin in human colorectal cancers. Int J Cancer 2009;125:2029-2035.

13 Mizuno Y, Hattori N, Mori H, Suzuki T, Tanaka K: Parkin and Parkinson's disease. Curr Opin Neurol 2001;14:477-482.

14 Mira MT, Alcaïs A, Van Thuc N, Thai VH, Huong NT, Ba NN, Verner A, Hudson TJ, Abel L, Schurr E: Chromosome 6q25 is linked to susceptibility to leprosy in a Vietnamese population. Nat Genet 2003;33:412-415.

15 Wongseree W, Assawamakin A, Piroonratana T, Sinsom-Ros S, Limwongse C, Chaiyaratana N: Detecting purely epistatic multi-locus interactions by an omnibus permutation test on ensembles of two-locus analyses. BMC Bioinformatics 2009;10:294.

16 Burns MP, Zhang L, Rebeck GW, Querfurth HW, Moussa CE: Parkin promotes intracellular Abeta1-42 clearance. Hum Mol Genet 2009;18:3206-3216.

17 Witte ME, Bol JG, Gerritsen WH, Van Der Valk P, Drukarch B, Van Horsen J, Wilhelmus MM: Parkinson's disease-associated parkin colocalizes with Alzheimer's disease and multiple sclerosis brain lesions. Neurobiol Dis 2009;36:445-452.
18 Jarick I, Volckmar AL, Pütter C, Pechlivanis S, Nguyen TT, Dauvermann MR, Beck S, Albayrak Ö, Scherag S, Gilsbach S, Cichon S, Hoffmann P, Degenhardt F, Nöthen MM, Schreiber S, Wichmann HE, Jöckel KH, Heinrich J, Tiesler CM, Faraone SV, Walitza S, Sinzig J, Freitag C, Meyer J, Herpertz-Dahlmann B, Lehmkuhl G, Renner TJ, Warnke A, Romanos M, Lesch KP, Reif A, Schimmelmann BG, Hebebrand J, Scherag A, Hinney A: Genome-wide analysis of rare copy number variations reveals PARK2 as a candidate gene for attention-deficit/hyperactivity disorder. Mol Psychiatry 2014;19:115-121.

19 Glessner JT, Wang K, Cai G, Korvatska O, Kim CE, Wood S, Zhang H, Estes A, Brune CW, Bradfield JP, Imielinski M, Frackelton EC, Reichert J, Crawford EL, Munson J, Sleiman PM, Chiavacci R, Annaiah K, Thomas K, Hou C, Glaberson W, Flory J, Otieno F, Garris M, Soorya L, Klei L, Piven J, Meyer KJ, Anagnostou E, Sakurai T, Game RM, Rudd DS, Zurawiecki D, McDougle CJ, Davis LK, Miller J, Posey DJ, Michaels S, Kolevzon A, Silverman JM, Bernier R, Levy SE, Schultz RT, Dawson G, Owley T, McMahon WM, Wassink TH, Sweeney JA, Nurnberger JI, Coon H, Sutcliffe JS, Minshew NJ, Grant SF, Bucan M, Cook EH, Buxbaum JD, Devlin B, Schellenberg GD, Hakonarson H: Autism genome-wide copy number variation reveals ubiquitin and neuronal genes. Nature 2009;459:569-573.

20 Kitada T, Asakawa S, Hattori N, Matsumine H, Yamamura Y, Minoshima S, Yokochi M, Mizuno Y, Shimizu N: Mutations in the parkin gene cause autosomal recessive juvenile parkinsonism. Nature 1998;392:605-608.

-21 Ali S, Vollaard AM, Widjaja S, Surjadi C, van de Vosse E, van Dissel JT: PARK2/PACRG polymorphisms and susceptibility to typhoid and paratyphoid fever. Clin Exp Immunol 2006;144:425-431. 
22 Bartek J, Hodny Z: PARK2 orchestrates cyclins to avoid cancer. Nat Genet 2014;46:527528.

$23 \mathrm{Xu}$ L, Lin DC, Yin D, Koeffler HP: An emerging role of PARK2 in cancer. J Mol Med (Berl) 2014;92:31-42.

24 Garnis C, Buys TPH, Lam WL: Genetic alteration and gene expression modulation during cancer progression. Mol Cancer 2004;3:3-9.

25 John SW, Weitzner G, Rozen R, Scriver Cohls: A rapid procedure for extracting genomic DNA from leukocytes. Nucleic Acids Res 1991;19:408.

26 Lahiri DK, Nurnberger JI Jr: A rapid non-enzymatic method for the preparation of HMW DNA from blood for RFLP studies. Nucleic Acids Res 1991;19:5444.

-27 Sellar GC, Watt KP, Rabiasz GJ, Stronach EA, Li L, Miller EP, Massie CE, Miller J, Contreras-Moreira B, Scott D, Brown I, Williams AR, Bates PA, Smyth JF, Gabra H: OPCML at $11 \mathrm{q} 25$ is epigenetically inactivated and has tumor-suppressor function in epithelial ovarian cancer. Nat Genet 2003;34:337-343.

28 Jones S, Wang TL, Shih IeM, Mao TL, Nakayama K, Roden R, Glas R, Slamon D, Diaz LA Jr, Vogelstein B, Kinzler KW, Velculescu VE, Papadopoulos N: Frequent mutations of chromatin remodeling gene ARID1A in ovarian clear cell carcinoma. Science 2010;330: 228-231

29 Carpten JD, Faber AL, Horn C, Donoho GP, Briggs SL, Robbins CM, Hostetter G, Boguslawski S, Moses TY, Savage S, Uhlik M, Lin A, Du J, Qian YW, Zeckner DJ, Tucker-Kellogg G, Touchman J, Patel K, Mousses S, Bittner M, Schevitz R, Lai MH, Blanchard KL, Thomas JE: A transforming mutation in the pleckstrin homology domain of AKT1 in cancer. Nature 2007;448:439-444.

30 Sagae S, Kobayashi K, Nishioka Y, Sugimura M, Ishioka S, Nagata $M$, Terasawa $K$, Tokino T, Kudo R: Mutational analysis of betacatenin gene in Japanese ovarian carcinomas: frequent mutations in endometrioid carcinomas. Jpn J Cancer Res 1999;90:510-515.

31 Stratton JF, Thompson D, Bobrow L, Dalal N, Gore M, Bishop DT, Scott I, Evans G, Daly P, Easton DF, Ponder BA: The genetic epidemiology of early-onset epithelial ovarian cancer: a population-based study. Am J Hum Genet 1999;65:1725-1732.

32 Gong Y, Zack TI, Morris LG, Lin K, Hukkelhoven E, Raheja R, Tan IL, Turcan S, Veeriah S, Meng S, Viale A, Schumacher SE, Palmedo P, Beroukhim R, Chan TA: Pan-cancer genetic analysis identifies PARK2 as a master regulator of G1/S cyclins. Nat Genet 2014;46:588-594.

- 33 Zhang C, Lin M, Wu R, Wang X, Yang B, Levine AJ, Hu W, Feng Z: Parkin, a p53 target gene, mediates the role of p53 in glucose metabolism and the Warburg effect. Proc Nat Acad Sci USA 2011;108:16259-16264.

34 Gabriel SB, Schaffner SF, Nguyen H, Moore JM, Roy J, Blumenstiel B, Higgins J, DeFelice M, Lochner A, Faggart M, Liu-Cordero SN, Rotimi C, Adeyemo A, Cooper R, Ward R, Lander ES, Daly MJ, Altshuler D: The structure of haplotype blocks in the human genome. Science 2002;296:2225-2229.

35 Croce CM, Calim GA: miRNAs, cancer, and stem cell division. Cell 2005;122:6-7.

36 Palumbo T, Faucz FR, Azevedo M, Xekouki P, Iliopoulos D, Stratakis CA: Functional screen analysis reveals miR-26b and miR-128 as central regulators of pituitary somatomammotrophic tumor growth through activation of the PTEN-AKT pathway. Oncogene 2013;32: 1651-1659.

37 Denison SR, Wang F, Becker NA, Schüle B, Kock N, Phillips LA, Klein C, Smith DI: Alterations in the common fragile site gene Parkin in ovarian and other cancers. Oncogene 2003;22:8370-8378. 